\title{
Optimum nitrogen management enhances growth, antioxidant ability and yield performance of rice in saline soil of coastal area of China
}

\author{
Guanglong Zhu ${ }^{1,2,3}$, Yue Wang ${ }^{1,2}$, Xiaoxu Shi ${ }^{2,3,4}$, Haitong $\mathrm{Lu}^{1,2}$, Zhen Ren $^{1,2,3}$, Yu Shi ${ }^{1,2,3}$, Xiurong Jiao ${ }^{1,2}$, \\ Muhi Eldeen Hussien Ibrahim ${ }^{1,5}$, Ahmad Irshad ${ }^{1,2}$, Wenbin Zhu ${ }^{4}$, Junbo Bian ${ }^{4}$, and Guisheng Zhou ${ }^{1,2,3^{*}}$ \\ 'Yangzhou University, Joint International Research Laboratory of Agriculture and Agri-Product Safety, Ministry of Education of China, \\ Yangzhou, 225009, China. \\ ${ }^{2}$ Yangzhou University, Agricultural College, Jiangsu Key Laboratory of Crop Genetics and Physiology/Jiangsu Key Laboratory of Crop \\ Cultivation and Physiology, Yangzhou 225009, China. \\ ${ }^{3}$ Yangzhou University, Jiangsu Co-Innovation Center for Modern Production Technology of Grain Crops, Yangzhou 225009, China. \\ *Corresponding author (gszhou@yzu.edu.cn). \\ ${ }^{4}$ Jiangsu Yanjiang Area Institute of Agricultural Sciences, Nantong 226000, China. \\ ${ }^{5}$ Sudan University of Science and Technology, College of Agricultural Studies, Department of Agronomy, Khartoum 13311, Sudan.
}

Received: 28 April 2020; Accepted: 29 July 2020; doi:10.4067/S0718-58392020000400629

\begin{abstract}
Salinity is a growing problem worldwide and techniques are needed to mitigate this problem. Field experiments were conducted to explore the effects of optimum $\mathrm{N}$ management (NM) on growth, antioxidant ability and yield performance of rice (Oryza sativa L.) in medium saline soil in the coastal area of Yancheng City, Jiangsu Province, China, during 2016 and 2017. A salt tolerant rice genotype Nangeng 9108 and $\mathrm{N}$ fertilizer including urea $\left(300 \mathrm{~kg} \mathrm{~N} \mathrm{ha}^{-1}\right)$ were used, six levels of NM were arranged (base:tillering:panicle initiation fertilizers = 0:8:2 (T1), 0:6:4 (T2), 0:4:6 (T3), 5.6:2.4:2.0 (T4), 4.2:1.8:4.0 (T5), and 2.8:1 .2:6.0 (T6), respectively). NM significantly affected plant growth, antioxidant traits, yield and yield components of rice in saline soil. On average, grain yield, panicles and spikelets per panicles were prominently higher under treatments of applied basal fertilizer (TABF; T4, T5 and T6) than treatments of non-applied basal fertilizer (TNBF; T1, T2 and T3). The TABF produced a yield advantaged of 39.7\% and 54.4\% over TNBF in 2016 and 2017, respectively. Bigger panicles were formed under TABF, mean spikelets per panicle was $15.7 \%$ higher than TNBF in 2016 and $20.0 \%$ in 2017. The T5 produced the highest dry weight, grain yield, panicles, spikelets per panicle, activities of catalase, peroxidase and superoxide dismutase, soluble protein, soluble sugar and sucrose at each growth period. However, the highest grain filling percentage showed under T4 had $82 \%$ and $81 \%$ advantages in each year. These results suggest that applied basal fertilizer can enhance salt tolerance and grain yield of rice, and appropriate $\mathrm{N}$ management can alleviate salt stress and increase grain yield.
\end{abstract}

Key words: Antioxidant ability, grain yield, nitrogen management, Oryza sativa, saline soil.

\section{INTRODUCTION}

Soil salinization is worsening than ever before, the area of saline agricultural soil is estimated to be about 800 million ha (Khan et al., 2014). It has becoming a major abiotic stress limiting crop growth and reducing grain yield (Islam et al., 2013). Sodium chloride stress leads to over accumulation of $\mathrm{Na}^{+}$and $\mathrm{Cl}$, which prevents acquisition and homeostasis of essential nutrient elements, like N, Ca and K, and induces oxidative stress in plants (Khan et al., 2010). Salinity affects the metabolisms of $\mathrm{C}$ and $\mathrm{N}$ in plants, which are the key physiological processes in determining plant growth and development (Touchette and Burkholder, 2007). 
Rice (Oryza sativa L.) is one of the most important cereals for human diet (Peng et al., 2005). Globally, about one third of rice production areas are affected by salinity (Prasad et al., 2000). Rice is highly susceptible to rhizosphere salinity than other cereal crops (Joseph et al., 2010). Rice genotypes show variable responses to salinity stress dependent on their growth stages (Ismail and Horie, 2017). Several studies confirmed that rice is tolerant to salinity during germination and vegetative stage, but sensitive at the early seedling stage and reproductive stage (Ismail et al., 2007). Under salinity stress, plant growth, tiller number, biomass, panicle number, spikelets per panicle, grain filling percentage, grain yield of rice significantly were declined (Abbas et al., 2015). These decreases are attributed to ion toxicity, nutrient deficiency and oxidative stress in salinity conditions (Flowers, 2004).

The adverse effects of salt stress on grain yield are attributed to two main causes: (1) Osmotic stress reduces water uptake by roots and causes internal dehydration, and (2) direct excessive accumulation of salts leads to ion toxicity that disturbs metabolic processes, particularly in photosynthetic cells (Ismail and Horie, 2017). Injury occurs when salts loaded in transpiring tissues surpass the ability of crops to extrude them from the cytoplasm, which largely depends on the mechanisms of $\mathrm{Na}^{+}$extrusion from roots, $\mathrm{Na}^{+}$unloading from the xylem, and $\mathrm{Na}^{+}$sequestration in vacuoles (Ismail et al., 2007). Under this situation, plant growth, leaf photosynthesis (Khan et al., 2015), water and nutrients uptake (Farooq et al., 2015), biomass accumulation and translocation (Pitann et al., 2011) and grain filling (Khan et al., 2017) were all significant declined.

Among nutrients, $\mathrm{N}$ is the key nutrient element for plant growth and production. Proper application of $\mathrm{N}$ fertilizer is a convenient and effective practice to improve plant growth, crop yield and quality. It has confirmed that $\mathrm{N}$ fertilization, different rates of $\mathrm{N}$ can alleviate the negative effects produced by salinity stresses (Ibrahim et al., 2018b), because N plays both nutritional and osmotic roles in saline conditions. However, it is difficult to optimize $\mathrm{N}$ application in crops because excessive or inadequate, untimely application may bring about other abiotic stresses. It has been reported that the growth inhibition and adverse effects induced by saline stress could be alleviated by proper use of fertilizer in crops such as maize (Akram et al., 2011), wheat (Ibrahim et al., 2018a), cotton (Chen et al., 2010) and oat (Song et al., 2019). However, little attention has paid to the effects of same amount of $\mathrm{N}$ with different managements on alleviating salt stress on rice plants in saline soil. It has confirmed that $\mathrm{N}$ fertilization can alleviate salinity tolerance of crops (Ibrahim et al., 2018a; Song et al., 2019). The possible reason was that $\mathrm{N}$ could play both nutritional and osmotic roles in saline conditions (Song et al., 2019). An increasing study confirmed that the growth inhibition and adverse effects induced by saline stress could be alleviated by proper use of $\mathrm{N}$ fertilizer (Ibrahim et al., 2018a; 2019).

It is uncertain whether that soil salinity can reduce the $\mathrm{N}$ metabolism in plants and there is a possibility that the utilization of $\mathrm{N}$ fertilizers can mitigate adverse influences of salinity and help to enhance the final yield of crops. The concentration of soluble cations and anions in the saline soil solution is high enough to make water stress, specific ion impacts and nutrient irregularity which normally decrease crop growth and yield. Normally, $\mathrm{N}$ fertilization improves productivity and yield of the crops at moderate soil salinity as compared to the situation where soil salinity is the main growth limiting factor (Ibrahim et al., 2018a). However, the $\mathrm{N}$ absorption and assimilation is critical for the rice yield increase when overdose $\mathrm{N}$ was applied in rice production (Wang et al., 2018).

Therefore, in this study, a 2-yr field experiment was conducted to study the effects of $\mathrm{N}$ management at the same rate on growth, antioxidant traits and yield performance of rice in the medium saline soil of coast area of China. The purposes of this study were to investigate the adverse effects of salt stress on plant growth, physiological traits and grain yield of rice; evaluate the alleviation effects of $\mathrm{N}$ managements on the above-mentioned parameters; and screen the optimum $\mathrm{N}$ management for rice production in the medium saline soil of coastal area of China.

\section{MATERIALS AND METHODS}

\section{Plant materials and experimental set-up}

A 2-yr field experiment was conducted on Shuntai Farm, Sheyang County ( $33^{\circ} 69^{\prime}$ N, $120^{\circ} 38^{\prime}$ E), Yancheng City, Jiangsu Province, China, during the two rice-growing seasons from May to October in 2016 and 2017. The soil from experiment field had a texture of sandy loam with $\mathrm{pH} 8.0-8.7$, organic matter $15.10 \mathrm{~g} \mathrm{~kg}^{-1}$, total N $66.42 \mathrm{mg} \mathrm{kg}^{-1}$, available $\mathrm{P} 22.19 \mathrm{mg} \mathrm{kg}^{-1}$, exchangeable $\mathrm{K} 93 \mathrm{mg} \mathrm{kg}^{-1}$, soil conductivity $2.5-3.5 \mathrm{dS} \mathrm{m}^{-1}$ (equivalent to content of sodium chloride $1.38-1.93 \mathrm{~g} \mathrm{~kg}^{-1}$ ). 
Rice (Oryza sativa L.) genotype Nangeng 9108 (screened in our previous study) was used in the experiment, a salt tolerant genotype with high grain quality and widely cultivated in China. Pre-germinated seeds were sown in a seedbed. Seedlings ( $27 \mathrm{~d}$ old) were transplanted on 5 June in 2016 and 9 June in 2017. The planting density was 27 hills m$^{-2}$ at a hill spacing of $30.0 \mathrm{~cm} \times 12.0 \mathrm{~cm}$ with three seedlings per hill $\left(2430\right.$ plant plot $\left.{ }^{-1}\right)$. Fertilizers included urea for $\mathrm{N}$ and single superphosphate for $\mathrm{P}$, and they were applied at $300 \mathrm{~kg} \mathrm{~N} \mathrm{ha}^{-1}$ and $40 \mathrm{~kg} \mathrm{P} \mathrm{ha}^{-1} . \mathrm{N}$ fertilizer was split-applied at basal $(1 \mathrm{~d}$ before transplanting), tillering ( $7 \mathrm{~d}$ after transplanting), and panicle initiation stage. Six levels of $\mathrm{N}$ management (NM) were arranged according to $\mathrm{N}$ rate at basal, tillering and panicle initiation (base:tillering:panicle initiation fertilizers). Treatments were 0:8:2 (T1), 0:6:4 (T2), 0:4:6 (T3), 5.6:2.4:2.0 (T4), 4.2:1.8:4.0 (T5) and 2.8:1.2:6.0 (T6); T1, T2 and $\mathrm{T} 3$ were classified as treatments of non-applied basal fertilizer (TNBF), and T4, T5 and T6 as treatments of applied basal fertilizer (TABF). Phosphorus was applied once as basal. The experiment was arranged in a randomized block design with three replicates and the plot size was $30 \mathrm{~m}^{2}(5 \times 6 \mathrm{~m})$. The experimental field was flooded from transplanting to $7 \mathrm{~d}$ before maturity. Pests and weeds were done in conformity with local recommendations.

\section{Measurements}

Growth, physiological and yield related parameters were assessed at different growth stages. Growth parameters included plant height and dry weight. Physiological parameters contained the activities of catalase (CAT), peroxidase (POD), superoxide dismutase (SOD) and the contents of soluble protein, soluble sugar and sucrose. Yield related parameters included grain yield, panicles, spikelets per panicle, grain filling percentage and grain weight.

Agronomic parameters. Twelve plants were sampled from each plot and used to measure plant height and dry weight at tillering, panicle initiation and heading stages. After measurement of plant height, plants were separated into root and shoot and then oven-dried at $80{ }^{\circ} \mathrm{C}$ to constant weight for biomass determination. After that, samples of each part were ground to powder to assay content of soluble sugar and sucrose.

Physiological parameters. At tillering, panicle initiation, and heading growth stages physiological parameters were measured. An additional 10 hills were sampled from each plot and the uppermost fully expanded leaves were used for physiological assays.

Catalase (CAT): About $0.1 \mathrm{~g}$ fresh leaf was homogenized in $5 \mathrm{~mL}$ assay mixtures contained $2.9 \mathrm{~mL}$ of substrate solution (30\% hydrogen peroxide in $50 \mathrm{mmol} \mathrm{L}^{-1}$ potassium phosphate buffer) and $0.1 \mathrm{~mL}$ enzyme extract. The decomposition of $\mathrm{H}_{2} \mathrm{O}_{2}$ was stopped by adding $2 \mathrm{~mL}$ potassium-dichromate (5\%). The optical density was taken at $620 \mathrm{~nm}$. The enzyme specific activity is expressed as mmol L-1 $\mathrm{H}_{2} \mathrm{O}_{2}$ oxidized per minute (mg protein) (Jini and Joseph, 2017).

Peroxidase (POD): $0.1 \mathrm{~g}$ fresh leaf was homogenized in $3 \mathrm{~mL} 0.1 \mathrm{M}$ phosphate buffer (pH 7.0) for the extraction of POD. The homogenate was centrifuged at $18000 \times g$ at $5{ }^{\circ} \mathrm{C}$ for $15 \mathrm{~min}$. The supernatant was used as enzyme source. $o$-Dianisidine $\left(1 \mathrm{mg} \mathrm{mL}^{-1}\right.$ methanol) was used as a substrate for the assay. The oxidized $o$-dianisidine (yellow/orange colored compound) was measured at $430 \mathrm{~nm}$. The phosphate buffer $\left(0.1 \mathrm{~mol} \mathrm{~L}^{-1}, \mathrm{pH} 6.5\right)$ was taken in a clean dry cuvette containing the enzyme extract and $0.1 \mathrm{~mL}$ freshly prepared $o$-dianisidine solution. Then, $0.2 \mathrm{~mL} 0.2 \mathrm{M} \mathrm{H}_{2} \mathrm{O}_{2}$ was added and mixed. The change in absorbance per minute was recorded. The enzyme activity was expressed in terms of rate of increased absorbance per minute per milligram protein (Assaha et al., 2017).

Superoxide dismutase (SOD): It was measured by the method of Jini and Joseph (2017). Fresh leaves $(0.2 \mathrm{~g})$ were homogenized in $5 \mathrm{~mL} 100 \mathrm{mmol} \mathrm{L}^{-1}$ potassium phosphate buffer (pH 7.8) containing $0.1 \mathrm{mmol} \mathrm{L}^{-1}$ EDTA, $0.1 \%$ Triton $\mathrm{X}-100$ and $2 \%$ polyvinyl pyrrolidone. The extract was filtered through muslin cloth and centrifuged at $15000 \times \mathrm{g}$ for $15 \mathrm{~min}$ at $4{ }^{\circ} \mathrm{C}$. The supernatant was used for the assay. The assay mixture in a total volume of $3 \mathrm{~mL}$ contained 50 mmol L-1 sodium carbonate/bicarbonate buffer ( $\mathrm{pH} 9.8$ ), $0.1 \mathrm{mmol} \mathrm{L}^{-1} \mathrm{EDTA}, 0.6 \mathrm{mmol} \mathrm{L}^{-1}$ epinephrine and enzyme. Epinephrine was the last component to be added. The adrenochrome formation in the next 4 min was recorded at 475 $\mathrm{nm}$ in a spectrophotometer (Shimadzu, Kyoto, Japan). One unit of SOD activity is expressed as the amount of enzyme required to cause $50 \%$ inhibition of epinephrine oxidation.

Soluble protein: A pre-weighed $0.5 \mathrm{~g}$ fresh leaf sample was frozen and ground to a fine powder with liquid $\mathrm{N}$ and extracted with $5 \mathrm{~mL}$ ice-cold potassium phosphate buffer with $1 \mathrm{mM}$ ascorbic acid (pH 7.8). The extract was clarified by centrifugation at $20000 \times \mathrm{g}$ and $4{ }^{\circ} \mathrm{C}$ for $20 \mathrm{~min}$. The supernatant layer was used for protein assays (Ella et al., 2003). 
Soluble sugar and sucrose were assayed in leaf and stem. About $0.1 \mathrm{~g}$ powders of leaf and stem were weighed, then extracted in $80 \%$ aqueous ethanol (v/v) 3 times. The extract was used for soluble carbohydrate analysis using anthrone reagent for soluble sugar and EDTA for sucrose (Fales, 1951).

\section{Yield and yield components}

At mature stage, the plants of 12 hills from each plot was used to determine yield components. After the panicles number was recorded, the plants were separated into straw and panicles. The straw dry weight was determined after the straw was oven-dried at $80{ }^{\circ} \mathrm{C}$ to a constant weight. The panicles were hand threshed, and the filled spikelets were separated from the unfilled spikelets by submerging the spikelets in tap water, then half-filled and empty spikelets were separated by a seed wind machine (FJ-I, Hangzhou Huier Instrument Equipment, Hangzhou, China). Subsequently, three subsamples of $30 \mathrm{~g}$ filled spikelets, three subsamples of $15 \mathrm{~g}$ half-filled spikelets, and three subsamples of $2 \mathrm{~g}$ empty spikelets were collected to count the number of spikelets. The dry weights of the rachis and filled, half-filled and empty spikelets (unfilled spikelets) were determined after they were oven-dried at $80{ }^{\circ} \mathrm{C}$ to a constant weight. The panicles, spikelets per panicle, 1000-grain weight, and harvest index were calculated (Zhu et al., 2016). About $5 \mathrm{~m}^{2}$ of plants were harvested to determine grain yield. The grain yield was adjusted to $14 \%$ moisture content. Grain moisture content was measured with a digital moisture tester (DMC-700, Seedburo Equipment Company, Des Plaines, Illinois, USA).

\section{Statistical analysis}

The study was conducted in two seasons, and results of statistical analysis showed that the experimental timings had similar results except for the data of yield and yield components. Consequently, by following Ibrahim et al. (2018a; 2018b) the mean of the two measurements of each variable was applied for statistical analysis. ANOVA was performed by factors design with Statistix 9.0 (Analytical Software, Tallahassee, Florida, USA), and the mean values were compared based on the least significant difference (LSD) test at $\mathrm{P}<0.05$. Figures were performed using SigmaPlot 10.0 (Systat Software, San Jose, California, USA).

\section{RESULTS}

\section{Plant height and dry weight}

Nitrogen management (NM) significantly affected plant height at tillering, panicle initiation and heading stages (Table 1). Generally, TNBF produced higher plant height than TABF. Among them, T3 showed the highest plant height with 36.00, 55.18 and $99.00 \mathrm{~cm}$ at each growth period, followed by T2 and T1. However, T5 generated the lowest plant height with 28.40 and $49.30 \mathrm{~cm}$ at tillering and panicle initiation stages, respectively, and T6 had the lowest plant height with 92.33 $\mathrm{cm}$ at heading stage (Table 1).

Significant effects of NM on dry weight were observed at both tillering and panicle initiation stages except for heading stage (Table 2). Opposite to plant height, more dry weight was produced under TABF rather than TNBF. T5 and T6 treatments produced the highest dry weight at each growth period, followed by T4. However, T1 showed the lowest dry weight with 85.6, 850.5 and $1884.1 \mathrm{~g} \mathrm{~m}^{-2}$ at tillering, panicle initiation and heading stages, respectively (Table 2).

Table 1. Effect of nitrogen management (NM) on rice plant height at different growth stages.

\begin{tabular}{|c|c|c|c|c|c|}
\hline NM & & Fertilizer arrangement & Tillering & $\begin{array}{l}\text { Panicle } \\
\text { initiation }\end{array}$ & Heading \\
\hline & & Base:tillering:panicle initiation & 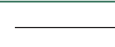 & $\mathrm{cm}$ & - \\
\hline \multirow[t]{3}{*}{ TNBF } & $\mathrm{T} 1$ & $0: 8: 2$ & $35.40 \mathrm{ab}$ & $53.12 b$ & $97.00 \mathrm{ab}$ \\
\hline & $\mathrm{T} 2$ & $0: 6: 4$ & $33.80 \mathrm{ab}$ & $53.40 \mathrm{ab}$ & $95.30 \mathrm{ab}$ \\
\hline & $\mathrm{T} 3$ & $0: 4: 6$ & $36.00 \mathrm{a}$ & $55.18 \mathrm{a}$ & $99.00 \mathrm{a}$ \\
\hline \multirow[t]{4}{*}{ TABF } & $\mathrm{T} 4$ & $5.6: 2.4: 2.0$ & $29.00 \mathrm{bc}$ & $50.98 \mathrm{bc}$ & $96.37 \mathrm{ab}$ \\
\hline & $\mathrm{T} 5$ & $4.2: 1.8: 4.0$ & $28.40 \mathrm{c}$ & $49.30 \mathrm{c}$ & $94.00 \mathrm{~b}$ \\
\hline & $\mathrm{T} 6$ & $2.8: 1.2: 6.0$ & $31.20 \mathrm{~b}$ & $51.68 \mathrm{bc}$ & $92.33 b$ \\
\hline & & F value & $6.41 * *$ & $3.42 *$ & $3.32 *$ \\
\hline
\end{tabular}

Values followed by different lowercase letters within different treatments are significantly different according to LSD test $(\mathrm{P}<0.05)$.

$*$,**Significant at $\mathrm{P} \leq 0.01$ and $\mathrm{P} \leq 0.05$, respectively; ns: nonsignificant.

TNBF: Treatments of non-applied basal fertilizer; TABF: treatments of applied basal fertilizer. 


\section{Yield and yield components}

Yield and yield components of rice were significantly affected by NM in both 2016 and 2017 (Table 3). Grain yield was prominently higher under TABF than TNBF. On average, TABF produced $39.7 \%$ and $54.4 \%$ more grain yield than TNBF in 2016 and 2017, respectively. The highest grain yield was showed by T5, which produced $9.52 \mathrm{t} \mathrm{ha}^{-1}$ in 2016 and $9.75 \mathrm{t} \mathrm{ha}^{-1}$ in 2017. On the contrary, the lowest grain yield was generated under T1 treatment in both years, which was only 4.76 and $4.73 \mathrm{t} \mathrm{ha}^{-1}$, respectively. In addition, under TNBF, grain yield was improved with decreased rate of tillering fertilizer and increased rate of panicle initiation fertilizer (Table 3 ).

The yield advantage of TABF was attributed to superior in panicles and spikelets per panicle. Similar to grain yield, panicles and spikelets per panicle were significantly higher in the TABF than the TNBF. The range of panicles under TNBF was from 287.96 to $329.63 \times 10^{4} \mathrm{ha}^{-1}$ in 2016 , and from 278.65 to $309.20 \times 10^{4} \mathrm{ha}^{-1}$ in 2017 . However, that was from 336.81 to $377.22 \times 10^{4} \mathrm{ha}^{-1}$ and from 345.49 to $379.57 \times 10^{4} \mathrm{ha}^{-1}$ under TABF in each year (Table 3 ). As for the spikelets per panicle, bigger panicles were formed under TABF, the mean spikelets per panicle were $15.7 \%$ and $20.0 \%$ higher than TNBF in 2016 and 2017, respectively. The spikelets per panicle gradually increased with the increased rate of panicle initiation fertilizer under TNBF. The maximum of spikelets per panicle was performed by T5 with 152.55 and 158.00, and the minimum was T1 with 117.05 and 116.45 in both 2016 and 2017, respectively (Table 3).

Table 2. Effect of nitrogen management (NM) on dry weight of rice at different growth stages.

\begin{tabular}{|c|c|c|c|c|c|}
\hline \multirow[t]{2}{*}{ NM } & \multirow{2}{*}{\multicolumn{2}{|c|}{$\begin{array}{c}\text { Fertilizer arrangement } \\
\text { Base:tillering:panicle initiation }\end{array}$}} & Tillering & $\begin{array}{c}\text { Panicle } \\
\text { initiation }\end{array}$ & \multirow[t]{2}{*}{ Heading } \\
\hline & & & 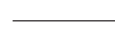 & $-\mathrm{g} \mathrm{m}^{-2}$ & \\
\hline \multirow{3}{*}{ TNBF } & $\mathrm{T} 1$ & $0: 8: 2$ & $85.6 \mathrm{~d}$ & $850.5 \mathrm{~d}$ & $1844.1 \mathrm{~b}$ \\
\hline & $\mathrm{T} 2$ & $0: 6: 4$ & $172.8 \mathrm{~b}$ & $1026.0 \mathrm{c}$ & $1927.8 \mathrm{~b}$ \\
\hline & $\mathrm{T} 3$ & $0: 4: 6$ & $110.7 \mathrm{c}$ & $850.5 \mathrm{~d}$ & $1844.1 b$ \\
\hline \multirow[t]{4}{*}{ TABF } & $\mathrm{T} 4$ & $5.6: 2.4: 2.0$ & 197.1ab & $999.0 \mathrm{c}$ & $2157.3 \mathrm{a}$ \\
\hline & T5 & $4.2: 1.8: 4.0$ & $213.3 \mathrm{a}$ & $1233.9 \mathrm{a}$ & $2251.8 \mathrm{a}$ \\
\hline & T6 & $2.8: 1.2: 6.0$ & $226.8 \mathrm{a}$ & $1161.0 \mathrm{~b}$ & $2168.1 \mathrm{a}$ \\
\hline & & F value & $45.6^{*}$ & $46.5^{*}$ & ns \\
\hline
\end{tabular}

Values followed by different lowercase letters within different treatments are significantly different according to LSD test $(\mathrm{P}<0.05)$.

*Significant at $\mathrm{P} \leq 0.01$; ns: nonsignificant.

TNBF: Treatments of non-applied basal fertilizer; TABF: treatments of applied basal fertilizer.

Table 3. Effect of nitrogen management (NM) on yield and yield components of rice in 2016 and 2017.

\begin{tabular}{|c|c|c|c|c|c|c|c|}
\hline NM & & $\begin{array}{c}\text { Fertilizer } \\
\text { arrangement }^{1}\end{array}$ & $\begin{array}{l}\text { Grain } \\
\text { yield }\end{array}$ & Panicles & $\begin{array}{l}\text { Spikelets per } \\
\text { panicle }\end{array}$ & $\begin{array}{l}\text { Grain } \\
\text { filling }\end{array}$ & $\begin{array}{c}\text { 1000-Grain } \\
\text { weight }\end{array}$ \\
\hline & & & $\mathrm{t} \mathrm{ha}^{-1}$ & $\times 10^{4} \mathrm{ha}^{-1}$ & & $\%$ & g \\
\hline \multicolumn{8}{|l|}{2016} \\
\hline \multirow[t]{3}{*}{ TNBF } & $\mathrm{T} 1$ & $0: 8: 2$ & $4.76 \mathrm{~d}$ & $287.96 b$ & $117.05 \mathrm{~b}$ & $59 \mathrm{e}$ & $23.95 \mathrm{a}$ \\
\hline & $\mathrm{T} 2$ & $0: 6: 4$ & $6.07 \mathrm{c}$ & $324.07 \mathrm{~b}$ & $120.52 b$ & $69 d$ & $22.51 \mathrm{ab}$ \\
\hline & $\mathrm{T} 3$ & $0: 4: 6$ & $7.33 \mathrm{c}$ & $329.63 \mathrm{ab}$ & $128.83 b$ & $75 b$ & $23.02 \mathrm{ab}$ \\
\hline \multirow[t]{4}{*}{ TABF } & $\mathrm{T} 4$ & $5.6: 2.4: 2.0$ & $8.03 \mathrm{~b}$ & $336.81 \mathrm{ab}$ & $134.02 \mathrm{ab}$ & $82 \mathrm{a}$ & $21.68 b$ \\
\hline & $\mathrm{T} 5$ & 4.2:1.8:4.0 & $9.52 \mathrm{a}$ & $377.22 \mathrm{a}$ & $152.55 \mathrm{a}$ & $71 \mathrm{c}$ & $23.31 \mathrm{ab}$ \\
\hline & T6 & $2.8: 1.2: 6.0$ & $7.77 b$ & $339.11 \mathrm{ab}$ & $137.37 \mathrm{ab}$ & $73 \mathrm{c}$ & $22.86 \mathrm{ab}$ \\
\hline & & $F$ value & $125.75^{* *}$ & $38.61 * *$ & $92.62 * *$ & $24.69 * *$ & $35.41 * *$ \\
\hline \multicolumn{8}{|l|}{2017} \\
\hline \multirow[t]{3}{*}{ TNBF } & $\mathrm{T} 1$ & $0: 8: 2$ & $4.73 d$ & $278.65 \mathrm{e}$ & $116.45 \mathrm{c}$ & $62 c$ & $23.55 \mathrm{a}$ \\
\hline & $\mathrm{T} 2$ & $0: 6: 4$ & $6.05 \mathrm{c}$ & $297.05 d$ & $120.29 b c$ & $75 b$ & $22.56 \mathrm{ab}$ \\
\hline & $\mathrm{T} 3$ & $0: 4: 6$ & $6.91 \mathrm{c}$ & $309.20 \mathrm{c}$ & $134.18 b$ & $77 b$ & $21.62 b$ \\
\hline \multirow[t]{4}{*}{ TABF } & $\mathrm{T} 4$ & $5.6: 2.4: 2.0$ & $8.86 b$ & $345.49 b$ & $141.31 \mathrm{abc}$ & $81 \mathrm{a}$ & $22.41 \mathrm{ab}$ \\
\hline & $\mathrm{T} 5$ & $4.2: 1.8: 4.0$ & $9.75 \mathrm{a}$ & $379.57 \mathrm{a}$ & $158.00 \mathrm{a}$ & $75 b$ & $21.68 b$ \\
\hline & T6 & $2.8: 1.2: 6.0$ & $8.71 \mathrm{~b}$ & $350.46 \mathrm{~b}$ & $145.50 \mathrm{ab}$ & $75 b$ & $22.79 \mathrm{ab}$ \\
\hline & & F value & $106.33 * *$ & $10.7 *$ & $46.63 * *$ & $28.98 * *$ & $42.86 * *$ \\
\hline
\end{tabular}

Values followed by different lowercase letters within different treatments are significantly different according to LSD test $(\mathrm{P}<0.05)$

$*$, **Significant at $\mathrm{P} \leq 0.01$ and $\mathrm{P} \leq 0.05$, respectively.

TNBF: Treatments of non-applied basal fertilizer; TABF: treatments of applied basal fertilizer.

${ }^{1}$ Base fertilizer:tillering fertilizer:panicle initiation fertilizer. 
However, under TNBF, grain filling percentage gradually increased but 1000-grain weight decreased with the declined rate of tillering fertilizer and increased panicle initiation fertilizer (Table 3). There is no obvious tendency for grain filling percentage and 1000-grain weight under TABF. The highest grain filling percentage showed under T4 with $82 \%$ and $81 \%$ in each year, followed by T3. But the lowest was T1 with 59\% in 2016 and 62\% in 2017. Interestingly, the maximum 1000-grain weight produced by T1 with 23.59 and $23.55 \mathrm{~g}$ in both 2016 and 2017. Oppositely, the minimum 1000-grain weight was T4 with $21.68 \mathrm{~g}$ in 2016, and T3 with $21.62 \mathrm{~g}$ in 2017 (Table 3).

\section{CAT, POD and SOD}

The activities of CAT, POD and SOD were significantly affected by NM at tillering, panicle initiation and heading stage (Tables 4, 5, and 6). As a whole, TABF produced higher activities of CAT, POD and SOD than TNBF at each growth period. On average, TABF showed 3.22, 1.68- and 1.80-times higher activity than TNBF at each growth stage for CAT, 1.83, 1.92 and 2.81 times higher for POD, and 4.15, 2.91 and 3.08 times higher for SOD. Among them, T5 of NM generated the highest activities of CAT, POD and SOD at these three growth periods, followed by T4 and T6.

Nitrogen management (NM) affected contents of soluble protein, soluble sugar and sucrose at each growth period, except for leaf soluble sugar at panicle initiation stage (Tables 7, 8,9,10 and 11). Either as a whole or as some stages, the mean contents of soluble protein, soluble sugar and sucrose under TABF were prominently higher than that under TNBF, but not to cover the contents of leaf soluble protein at heading stage (Table 7), leaf soluble sugar at both heading and maturity stage (Table 8), and leaf sucrose at heading stage (Table 10). Nevertheless, still T5, one of the TABF of NM, produced the highest content of soluble protein, soluble sugar and sucrose at each growth period.

Table 4. Effect of nitrogen management (NM) on catalase (CAT) activity of rice leaves at different growth stages.

\begin{tabular}{|c|c|c|c|c|c|}
\hline NM & & Fertilizer arrangement & Tillering & $\begin{array}{c}\text { Panicle } \\
\text { initiation }\end{array}$ & Heading \\
\hline & & Base:tillering:panicle initiation & $\longrightarrow$ & $-\mathrm{Ug}^{-1} \mathrm{FW}$ & 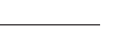 \\
\hline \multirow[t]{3}{*}{ TNBF } & $\mathrm{T} 1$ & $0: 8: 2$ & $118.99 \mathrm{~cd}$ & $100.43 \mathrm{f}$ & $65.93 \mathrm{f}$ \\
\hline & $\mathrm{T} 2$ & $0: 6: 4$ & $77.14 \mathrm{~d}$ & $124.07 \mathrm{e}$ & $107.16 \mathrm{e}$ \\
\hline & $\mathrm{T} 3$ & $0: 4: 6$ & $62.96 \mathrm{~d}$ & $178.19 \mathrm{~d}$ & $125.90 \mathrm{~d}$ \\
\hline \multirow[t]{4}{*}{ TABF } & $\mathrm{T} 4$ & $5.6: 2.4: 2.0$ & $274.40 \mathrm{~b}$ & $201.48 b$ & $186.45 \mathrm{~b}$ \\
\hline & T5 & $4.2: 1.8: 4.0$ & $366.48 \mathrm{a}$ & $287.38 \mathrm{a}$ & $195.85 \mathrm{a}$ \\
\hline & $\mathrm{T} 6$ & $2.8: 1.2: 6.0$ & $193.88 \mathrm{c}$ & $186.85 \mathrm{c}$ & $156.26 \mathrm{c}$ \\
\hline & & F value & $16.70 * *$ & $20.30 * *$ & $12.84 * *$ \\
\hline
\end{tabular}

Values followed by different lowercase letters within different treatments are significantly different according to LSD test $(\mathrm{P}<0.05)$.

$* *$ Significant at $\mathrm{P} \leq 0.05$.

TNBF: Treatments of non-applied basal fertilizer; TABF: treatments of applied basal fertilizer.

Table 5. Effect of nitrogen management (NM) on leaf peroxidase (POD) activity of rice at different growth stages.

\begin{tabular}{|c|c|c|c|c|c|}
\hline \multirow[t]{2}{*}{ NM } & \multicolumn{2}{|r|}{ Fertilizer arrangement } & Tillering & $\begin{array}{l}\text { Panicle } \\
\text { initiation }\end{array}$ & Heading \\
\hline & \multicolumn{2}{|r|}{ Base:tillering:panicle initiation } & $\longrightarrow$ & $-\mathrm{U} \mathrm{g}^{-1} \mathrm{FW}$ & - \\
\hline \multirow[t]{3}{*}{ TNBF } & $\mathrm{T} 1$ & $0: 8: 2$ & $159.67 d$ & $159.24 d$ & $50.17 \mathrm{f}$ \\
\hline & $\mathrm{T} 2$ & $0: 6: 4$ & $136.43 \mathrm{e}$ & $101.08 \mathrm{e}$ & $63.58 \mathrm{e}$ \\
\hline & T3 & $0: 4: 6$ & $118.70 \mathrm{f}$ & $83.42 \mathrm{f}$ & $75.00 \mathrm{~d}$ \\
\hline \multirow[t]{4}{*}{ TABF } & $\mathrm{T} 4$ & $5.6: 2.4: 2.0$ & $228.20 \mathrm{~b}$ & $200.96 b$ & $172.00 \mathrm{~b}$ \\
\hline & T5 & $4.2: 1.8: 4.0$ & $325.52 \mathrm{a}$ & $284.30 \mathrm{a}$ & 209.20a \\
\hline & T6 & $2.8: 1.2: 6.0$ & $204.82 \mathrm{c}$ & $175.42 \mathrm{c}$ & $148.32 \mathrm{c}$ \\
\hline & \multicolumn{2}{|r|}{ F value } & $38.03 * *$ & $12.11 * *$ & $13.51^{* *}$ \\
\hline
\end{tabular}

Values followed by different lowercase letters within different treatments are significantly

different according to LSD test $(\mathrm{P}<0.05)$

$* *$ Significant at $\mathrm{P} \leq 0.05$.

TNBF: Treatments of non-applied basal fertilizer; TABF: treatments of applied basal fertilizer. 
Table 6. Effect of nitrogen management (NM) on leaf superoxide dismutase activity (SOD) of rice at different growth stages.

\begin{tabular}{|c|c|c|c|c|c|}
\hline \multirow[t]{2}{*}{ NM } & \multirow{2}{*}{\multicolumn{2}{|c|}{$\begin{array}{c}\text { Fertilizer arrangement } \\
\text { Base:tillering:panicle initiation }\end{array}$}} & Tillering & $\begin{array}{l}\text { Panicle } \\
\text { initiation }\end{array}$ & Heading \\
\hline & & & \multicolumn{3}{|c|}{$\longrightarrow \mathrm{U} \mathrm{g}^{-1} \mathrm{FW}$} \\
\hline \multirow[t]{3}{*}{ TNBF } & $\mathrm{T} 1$ & $0: 8: 2$ & $74.14 d$ & $26.86 \mathrm{f}$ & $10.90 \mathrm{f}$ \\
\hline & $\mathrm{T} 2$ & $0: 6: 4$ & $54.20 \mathrm{e}$ & $43.63 \mathrm{e}$ & $26.34 \mathrm{e}$ \\
\hline & $\mathrm{T} 3$ & $0: 4: 6$ & $43.24 \mathrm{f}$ & $61.19 \mathrm{~d}$ & $47.25 \mathrm{~d}$ \\
\hline \multirow[t]{4}{*}{ TABF } & $\mathrm{T} 4$ & $5.6: 2.4: 2.0$ & $252.02 \mathrm{~b}$ & $118.69 \mathrm{~b}$ & $87.24 \mathrm{~b}$ \\
\hline & T5 & $4.2: 1.8: 4.0$ & $270.58 \mathrm{a}$ & $172.6 \mathrm{a}$ & $107.38 \mathrm{a}$ \\
\hline & T6 & $2.8: 1.2: 6.0$ & $189.39 \mathrm{c}$ & $91.71 \mathrm{c}$ & $65.25 \mathrm{c}$ \\
\hline & & F value & $97.7 * *$ & $31.63 * *$ & $31.91 * *$ \\
\hline
\end{tabular}

Values followed by different lowercase letters within different treatments are significantly different according to LSD test $(\mathrm{P}<0.05)$.

$* *$ Significant at $\mathrm{P} \leq 0.05$.

TNBF: Treatments of non-applied basal fertilizer; TABF: treatments of applied basal fertilizer.

Table 7. Effect of nitrogen management (NM) on leaf soluble protein content of rice at different growth stages.

\begin{tabular}{lllccc}
\hline NM & \multicolumn{1}{c}{ Fertilizer arrangement } & Tillering & $\begin{array}{c}\text { Panicle } \\
\text { initiation }\end{array}$ & Heading \\
\cline { 4 - 5 } TNBF & T1 & $0: 8: 2$ & & $\mathrm{mg} \mathrm{g}^{-1} \mathrm{FW}$ & \\
\cline { 3 - 5 } & T2 & $0: 6: 4$ & $19.07 \mathrm{c}$ & $24.28 \mathrm{bc}$ & $16.90 \mathrm{a}$ \\
& T3 & $0: 4: 6$ & $24.08 \mathrm{~b}$ & $23.30 \mathrm{~cd}$ & $19.32 \mathrm{a}$ \\
TABF & T4 & $5.6: 2.4: 2.0$ & $33.09 \mathrm{a}$ & $15.82 \mathrm{e}$ & $16.74 \mathrm{a}$ \\
& T5 & $4.2: 1.8: 4.0$ & $19.03 \mathrm{c}$ & $26.46 \mathrm{~b}$ & $13.30 \mathrm{~b}$ \\
& T6 & $2.8: 1.2: 6.0$ & $35.52 \mathrm{a}$ & $30.08 \mathrm{a}$ & $17.61 \mathrm{a}$ \\
& & $22.87 \mathrm{~b}$ & $20.95 \mathrm{~d}$ & $7.49 \mathrm{c}$ \\
\hline
\end{tabular}

Values followed by different lowercase letters within different treatments are significantly different according to LSD test $(\mathrm{P}<0.05)$.

$*, * *$ Significant at $\mathrm{P} \leq 0.01$ and $\mathrm{P} \leq 0.05$, respectively.

TNBF: Treatments of non-applied basal fertilizer; TABF: treatments of applied basal fertilizer.

Table 8. Effect of nitrogen management (NM) on leaf soluble sugar content of rice at different growth stages.

\begin{tabular}{|c|c|c|c|c|c|c|}
\hline \multirow[t]{2}{*}{ NM } & \multirow{2}{*}{\multicolumn{2}{|c|}{$\begin{array}{c}\text { Fertilizer arrangement } \\
\text { Base:tillering:panicle initiation }\end{array}$}} & Tillering & $\begin{array}{l}\text { Panicle } \\
\text { initiation }\end{array}$ & Heading & \multirow[t]{2}{*}{ Maturity } \\
\hline & & & 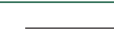 & ${ }_{1}$ & $\mathrm{~g}^{-1}$ & \\
\hline \multirow[t]{3}{*}{ TNBF } & $\mathrm{T} 1$ & $0: 8: 2$ & $0.48 \mathrm{c}$ & $0.76 \mathrm{ab}$ & $0.70 \mathrm{bc}$ & $0.54 \mathrm{~b}$ \\
\hline & $\mathrm{T} 2$ & $0: 6: 4$ & $0.52 b c$ & $0.72 b$ & $0.78 \mathrm{~b}$ & $0.59 \mathrm{ab}$ \\
\hline & $\mathrm{T} 3$ & $0: 4: 6$ & $0.55 b$ & $0.74 \mathrm{ab}$ & $1.08 \mathrm{a}$ & $0.56 \mathrm{~b}$ \\
\hline \multirow[t]{4}{*}{ TABF } & $\mathrm{T} 4$ & $5.6: 2.4: 2.0$ & $0.55 b$ & $0.74 \mathrm{ab}$ & $0.72 b c$ & $0.58 \mathrm{ab}$ \\
\hline & $\mathrm{T} 5$ & $4.2: 1.8: 4.0$ & $0.71 \mathrm{a}$ & $0.85 a$ & $1.12 \mathrm{a}$ & $0.64 \mathrm{a}$ \\
\hline & $\mathrm{T} 6$ & $2.8: 1.2: 6.0$ & $0.39 \mathrm{~d}$ & $0.79 \mathrm{ab}$ & $0.56 \mathrm{c}$ & $0.27 \mathrm{c}$ \\
\hline & & F value & $4.98^{*}$ & ns & $17.19^{* *}$ & $55.57 * *$ \\
\hline
\end{tabular}

Values followed by different lowercase letters within different treatments are significantly different according to LSD test $(\mathrm{P}<0.05)$.

$*$, ** Significant at $\mathrm{P} \leq 0.01$ and $\mathrm{P} \leq 0.05$, respectively; ns: nonsignificant.

TNBF: Treatments of non-applied basal fertilizer; TABF: treatments of applied basal fertilizer. 
Table 9. Effect of nitrogen management (NM) on stem soluble sugar content of rice at different growth stages.

\begin{tabular}{|c|c|c|c|c|c|}
\hline \multirow[t]{2}{*}{$\mathrm{NM}$} & & Fertilizer arrangement & $\begin{array}{l}\text { Panicle } \\
\text { initiation }\end{array}$ & Heading & Maturity \\
\hline & & Base:tillering:panicle initiation & & $\mathrm{mg} \mathrm{g}^{-1}$ & 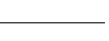 \\
\hline \multirow[t]{3}{*}{ TNBF } & $\mathrm{T} 1$ & $0: 8: 2$ & $0.66 \mathrm{ab}$ & $0.58 \mathrm{c}$ & $0.30 \mathrm{~b}$ \\
\hline & $\mathrm{T} 2$ & $0: 6: 4$ & $0.50 \mathrm{c}$ & $0.70 \mathrm{~b}$ & $0.33 \mathrm{ab}$ \\
\hline & T3 & $0: 4: 6$ & $0.66 \mathrm{ab}$ & $0.66 \mathrm{bc}$ & $0.27 \mathrm{~b}$ \\
\hline \multirow[t]{4}{*}{ TABF } & $\mathrm{T} 4$ & $5.6: 2.4: 2.0$ & $0.63 \mathrm{ab}$ & $0.68 b c$ & $0.27 b$ \\
\hline & T5 & $4.2: 1.8: 4.0$ & $0.76 \mathrm{a}$ & $1.08 \mathrm{a}$ & $0.43 \mathrm{a}$ \\
\hline & T6 & $2.8: 1.2: 6.0$ & $0.59 \mathrm{bc}$ & $0.67 b c$ & $0.35 \mathrm{ab}$ \\
\hline & & F value & $6.44 * *$ & $36.57 * *$ & $4.68^{*}$ \\
\hline
\end{tabular}

Values followed by different lowercase letters within different treatments are significantly different according to LSD test $(\mathrm{P}<0.05)$.

$*, * *$ Significant at $\mathrm{P} \leq 0.01$ and $\mathrm{P} \leq 0.05$, respectively.

TNBF: Treatments of non-applied basal fertilizer; TABF: treatments of applied basal fertilizer.

Table 10. Effect of nitrogen management (NM) on leaf sucrose content of rice at different growth stages.

\begin{tabular}{|c|c|c|c|c|c|c|}
\hline \multirow[t]{2}{*}{$\mathrm{NM}$} & \multirow{2}{*}{\multicolumn{2}{|c|}{$\begin{array}{c}\text { Fertilizer arrangement } \\
\text { Base:tillering:panicle initiation }\end{array}$}} & Tillering & \multirow[t]{2}{*}{$\begin{array}{l}\text { Panicle } \\
\text { initiation }\end{array}$} & \multirow[t]{2}{*}{ Heading } & \multirow[t]{2}{*}{ Maturity } \\
\hline & & & - & & & \\
\hline \multirow[t]{3}{*}{ TNBF } & $\mathrm{T} 1$ & $0: 8: 2$ & $0.23 \mathrm{e}$ & $0.65 b$ & $0.57 \mathrm{~b}$ & $0.29 \mathrm{ab}$ \\
\hline & $\mathrm{T} 2$ & $0: 6: 4$ & $0.51 \mathrm{ab}$ & $0.48 \mathrm{c}$ & $0.58 \mathrm{~b}$ & $0.21 \mathrm{c}$ \\
\hline & $\mathrm{T} 3$ & $0: 4: 6$ & $0.45 \mathrm{bc}$ & $0.65 b$ & $0.49 b c$ & $0.23 \mathrm{c}$ \\
\hline \multirow[t]{4}{*}{ TABF } & $\mathrm{T} 4$ & $5.6: 2.4: 2.0$ & $0.40 \mathrm{~cd}$ & $0.71 b$ & $0.50 \mathrm{bc}$ & $0.22 \mathrm{c}$ \\
\hline & T5 & $4.2: 1.8: 4.0$ & $0.59 a$ & $0.82 \mathrm{a}$ & $0.68 \mathrm{a}$ & $0.32 \mathrm{a}$ \\
\hline & T6 & $2.8: 1.2: 6.0$ & $0.32 \mathrm{de}$ & $0.67 b$ & $0.44 \mathrm{c}$ & $0.25 b c$ \\
\hline & & $F$ value & $28.83 * *$ & $26.76 * *$ & $16.08 * *$ & $10.51 * *$ \\
\hline
\end{tabular}

Values followed by different lowercase letters within different treatments are significantly different according to LSD test $(\mathrm{P}<0.05)$.

$* *$ Significant at $\mathrm{P} \leq 0.05$.

TNBF: Treatments of non-applied basal fertilizer; TABF: treatments of applied basal fertilizer.

Table 11. Effect of nitrogen management (NM) on stem sucrose content of rice at different growth stages.

\begin{tabular}{|c|c|c|c|c|c|}
\hline \multirow[t]{2}{*}{ NM } & & Fertilizer arrangement & $\begin{array}{l}\text { Panicle } \\
\text { initiation }\end{array}$ & Heading & Maturity \\
\hline & & Base:tillering:panicle initiation & 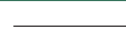 & $\mathrm{mg} \mathrm{g}^{-1}$ & \\
\hline \multirow[t]{3}{*}{ TNBF } & $\mathrm{T} 1$ & $0: 8: 2$ & $0.52 \mathrm{bc}$ & $0.22 \mathrm{~d}$ & $0.12 b$ \\
\hline & $\mathrm{T} 2$ & $0: 6: 4$ & $0.49 \mathrm{bcd}$ & $0.23 \mathrm{~cd}$ & $0.14 \mathrm{~b}$ \\
\hline & $\mathrm{T} 3$ & $0: 4: 6$ & $0.39 \mathrm{~cd}$ & $0.27 \mathrm{~cd}$ & $0.24 \mathrm{a}$ \\
\hline \multirow[t]{4}{*}{ TABF } & $\mathrm{T} 4$ & $5.6: 2.4: 2.0$ & $0.59 \mathrm{ab}$ & $0.46 \mathrm{ab}$ & $0.09 \mathrm{~b}$ \\
\hline & T5 & $4.2: 1.8: 4.0$ & $0.74 \mathrm{a}$ & $0.57 \mathrm{a}$ & $0.25 \mathrm{a}$ \\
\hline & T6 & $2.8: 1.2: 6.0$ & $0.35 \mathrm{~d}$ & $0.36 \mathrm{bc}$ & $0.21 \mathrm{a}$ \\
\hline & & $F$ value & $11.57 * *$ & $18.73^{* *}$ & $12.59 * *$ \\
\hline
\end{tabular}

Values followed by different lowercase letters within different treatments are significantly different according to LSD test $(\mathrm{P}<0.05)$.

$* *$ Significant at $\mathrm{P} \leq 0.05$.

TNBF: Treatments of non-applied basal fertilizer; TABF: treatments of applied basal fertilizer.

\section{DISCUSSION}

Among abiotic stresses, salt stress is especially important in crop production because it can significantly decrease crop productivity. As showed in the present study, grain yield, panicles, spikelets per panicle and grain filling percentage were all lower in TNBF than TABF in saline soil. Similar results were showed by Abbas et al. (2015), who reported that grain yield and yield components of rice significantly declined under salinity stress. Those results were also confirmed in the present study, plant height, dry weight, activity of anti-oxidase enzymes, soluble protein and soluble sugar were all affected by salinity stress. 
The decrease of yield and its component determined under salt stress may also be correlated with low production, growth, senescence and physiologically limited active green foliage, and consequently decreased photosynthetic rate. The physiological properties also represent an important direct or indirect role in the reduction of efficiency of the plant and may direct to reduced grain yield. However, over fertilization with $\mathrm{N}$ may add to soil salinization and enhance the adverse impacts of salinity on plant production. In addition, the potential for $\mathrm{NO}_{3}$ leaching may improve soils with moderate to high quantities of salts because plants under salinity stress cannot absorb and use the utilized $\mathrm{N}$ efficiently. Subsequently, careful fertilizer management is crucial in salt-affected soils to sustain yields and to reduce the degradation of soil (Chen et al., 2010).

In the present study, growth, antioxidant and yield related traits were prominently higher under TABF than TNBF. The TABF produced a yield advantage of 39.7\% and 54.4\% than TNBF in 2016 and 2017, respectively. These results suggest that applied basal fertilizer can enhance salt tolerance and improve grain yield of rice. The possible reason was that moderate basal fertilizer produced a higher early vigor of rice seedlings, which improved photosynthetic productivity, biomass accumulation, and ultimately superior in grain yield (Song et al., 2019). Among them, T5 (4.2:1.8:4.0), the optimum NM performed the best alleviation effects for grain yield and most of evaluated parameters. These results suggested that moderate fertilizer with appropriate management could also effectively alleviate adversity stresses and promote plant growth and grain yield. Our results are in dealing with the findings of Usman et al. (2013) who stated that $\mathrm{N}$ fertilizer improved yield. Ibrahim et al. (2019) also stated that $\mathrm{N}$ fertilization can decrease some of the harmful effects of salinity on the plant. Furthermore, the results of Ibrahim et al. (2019) on wheat revealed that $\mathrm{N}$ fertilizer had a positive influence on plant growth under salinity stress. However, their findings did not reveal any clear trend to show that $\mathrm{N}$ levels had a direct effect on alleviating the reduced growth caused by salinity.

In the present study, decreased in plant height, dry weight, panicle number and grain yield under salinity conditions were partly attributed to the osmotic stress and $\mathrm{Na}^{+}$toxicity, which lead to generating of reactive oxygen species (ROS) (Munns and Tester, 2008). The TABF could significantly increase antioxidant ability of rice under salt stress. This increment in antioxidant enzymes might be due to the activation of plant resistance mechanisms (Wang et al., 2016). Catalase in peroxisomes breaks down $\mathrm{H}_{2} \mathrm{O}_{2}$. Peroxidase in cytosol and chloroplast can correctly scavenge $\mathrm{H}_{2} \mathrm{O}_{2}$. An increase of peroxidase activity by salt treatment in plants has also been reported by Kahrizi et al. (2012). Nitrogen fertilizer have been revealed to mitigate salt stress in plants by improving the synthesis of antioxidant enzymes in plants (Ibrahim et al., 2018b). We agree with that, especially in T5 of NM which produced the highest activities of CAT, POD and SOD, contents of soluble protein, soluble sugar and sucrose at each growth period. The SOD, POD and CAT belong to the enzymatic system, which are the first defense line against ROS stress, catalyzing dismutation or conversion of radical $\mathrm{O}_{2}$ - into $\mathrm{H}_{2} \mathrm{O}_{2}$ (Bose et al., 2014), and decomposes $\mathrm{H}_{2} \mathrm{O}_{2}$ into $\mathrm{O}_{2}$ and $\mathrm{H}_{2} \mathrm{O}$ (Willekens et al., 1997), ultimately avoiding rice to suffer serious damage from ROS (Deisseroth and Dounce, 1970). The soluble sugar and soluble protein belong to nonenzymatic system, which act as osmoprotectants and compatible solute for osmotic adjustments and antioxidants or ROS quenchers (Iqbal et al., 2018). These results suggest that applied basal fertilizer of NM enhance antioxidant ability of rice under salinity by improving activities of both enzymatic system and non-enzymatic system.

\section{CONCLUSIONS}

Nitrogen management (NM) significantly enhanced plant growth, antioxidant ability and yield performance of rice in saline soil. On average, grain yield, panicles and spikelets per panicles were prominently higher under applied basal fertilizer NM than non-basal fertilizer NM. In general, the optimum NM was base:tillering:panicle initiation fertilizers 4.2:1.8:4.0 (T5), which produced the highest dry weight, grain yield, panicles, spikelets per panicle, activities of catalase, peroxidase and superoxide dismutase, contents of soluble protein, soluble sugar and sucrose in salinity stress. These results suggest that applied basal fertilizer can enhance salt tolerant and grain yield of rice, optimum N management (T5) can effectively alleviate salt stress and increase grain yield. 


\section{ACKNOWLEDGEMENTS}

This work was partially funded by China National Key Research and Development Program (2017YFD0301205), the Natural Science Foundation of Jiangsu Province of China (BK20180923), Post-doctoral Fund of Jiangsu Province of China (2018K231C), "LvYangJinFeng" project of Yangzhou City Government of Jiangsu Province of China (2018), Jiangsu Provincial Agricultural Innovation Fund (CX16(1005), Science and Technology Innovation Cultivating fund of Yangzhou University (2019CXJ198), and the Natural Science Foundation of Jiangsu Higher Education Institutions of China (17KJB210008). Zhu Guanglong, Wang Yue, Shi Xiaoxu, \& Muhi Eldeen Hussien Ibrahim contribute equally to this paper and are considered the first co-authors

\section{REFERENCES}

Abbas, G., Saqib, M., Akhtar, J., and Haq, M.A.U. 2015. Interactive effects of salinity and iron deficiency on different rice genotypes. Journal of Plant Nutrition and Soil Science 178:306-311.

Akram, M., Ashraf, M., Jamil, M., Iqbal, R., Nafees, M., and Khan, M. 2011. Nitrogen application improves gas exchange characteristics and chlorophyll fluorescence in maize hybrids under salinity conditions. Russian Journal of Plant Physiology 58:394-401.

Assaha, D., Mekawy, A., Liu, L., Noori, M., Kokulan, K., Ueda, A., et al. 2017. $\mathrm{Na}^{+}$retention in the root is a key adaptive mechanism to low and high salinity in the glycophyte, Talinum paniculatum (Jacq.) Gaertn. (Portulacaceae). Journal of Agronomy and Crop Science 203:56-67.

Bose, J., Rodrigo-Moreno, A., and Shabala, S. 2014. ROS homeostasis in halophytes in the context of salinity stress tolerance. Journal of Experimental Botany 65:1241-1257.

Chen, W., Hou, Z., Wu, L., Liang, Y., and Wei, C. 2010. Effects of salinity and nitrogen on cotton growth in arid environment. Plant and Soil 326:61-73.

Deisseroth, A., and Dounce, A.L. 1970. Catalase: Physical and chemical properties, mechanism of catalysis, and physiological role. Physiological Reviews 50:319-375.

Ella, E.S., Kawano, N., and Ito, O. 2003. Importance of active oxygen-scavenging system in the recovery of rice seedlings after submergence. Plant Science 165:85-93.

Fales, F.W. 1951. The assimilation and degradation of carbohydrates by yeast cells. Journal of Biological Chemistry 193:113-124.

Farooq, M., Hussain, M., Wakeel, A., and Siddique, K.H. 2015. Salt stress in maize: effects, resistance mechanisms, and management. A review. Agronomy for Sustainable Development 35:461-481.

Flowers, T. 2004. Improving crop salt tolerance. Journal of Experimental Botany 55:307-319.

Ibrahim, M.E.H., Zhu, X., Zhou, G., Ali, A.Y.A., Ahmad, I., and Elsiddig, A.M.I. 2018a. Nitrogen fertilizer reduces the impact of sodium chloride on wheat yield. Agronomy Journal 110:1731-1737.

Ibrahim, M.E.H., Zhu, X., Zhou, G., Ali, A.Y.A., Ahmad, I., Elsiddig, A.M.I., et al. 2019. Promoting salt tolerance in wheat seedlings by application of nitrogen fertilizer. Pakistan Journal of Botany 51:1995-2002.

Ibrahim, M.E.H., Zhu, X., Zhou, G., Ali, A.Y.A., Ahmad, I., and Farah, G.A. 2018b. Nitrogen fertilizer alleviated negative impacts of $\mathrm{NaCl}$ on some physiological parameters of wheat. Pakistan Journal of Botany 50:2097-2104.

Iqbal, H., Yaning, C., Waqas, M., Rehman, H., Shareef, M., and Iqbal, S. 2018. Hydrogen peroxide application improves quinoa performance by affecting physiological and biochemical mechanisms under water-deficit conditions. Journal of Agronomy and Crop Science 204:541-553.

Islam, M., Sattar, M., Ashrafuzzaman, M., Zulkerami, B., and Shamsuddoha, A. 2013. Evaluating some salinity tolerant rhizobacterial strains to lentil production under salinity stress. International Journal of Agriculture and Biology 15(3):499-504.

Ismail, A.M., Heuer, S., Thomson, M.J., and Wissuwa, M. 2007. Genetic and genomic approaches to develop rice germplasm for problem soils. Plant Molecular Biology 65:547-570.

Ismail, A.M., and Horie, T. 2017. Genomics, physiology, and molecular breeding approaches for improving salt tolerance. Annual Review of Plant Biology 68:405-434.

Jini, D., and Joseph, B. 2017. Physiological mechanism of salicylic acid for alleviation of salt stress in rice. Rice Science 24:97-108.

Joseph, B., Jini, D., and Sujatha, S. 2010. Biological and physiological perspectives of specificity in abiotic salt stress response from various rice plants. Asian Journal of Agricultural Science 2:99-105.

Kahrizi, S., Sedighi, M., and Sofalian, O. 2012. Effect of salt stress on proline and activity of antioxidant enzymes in ten durum wheat cultivars. Annals of Biological Research 3:3870-3874.

Khan, M.I.R., Asgher, M., and Khan, N.A. 2014. Alleviation of salt-induced photosynthesis and growth inhibition by salicylic acid involves glycinebetaine and ethylene in mungbean (Vigna radiata L.) Plant Physiology and Biochemistry 80:67-74.

Khan, H.A., Siddique, K.H., and Colmer, T.D. 2017. Vegetative and reproductive growth of salt-stressed chickpea are carbonlimited: sucrose infusion at the reproductive stage improves salt tolerance. Journal of Experimental Botany 68:2001-2011. 
Khan, H.A., Siddique, K.H., Munir, R., and Colmer, T.D. 2015. Salt sensitivity in chickpea: growth, photosynthesis, seed yield components and tissue ion regulation in contrasting genotypes. Journal of Plant Physiology 182:1-12.

Khan, N., Syeed, S., Masood, A., Nazar, R., and Iqbal, N. 2010. Application of salicylic acid increases contents of nutrients and antioxidative metabolism in mungbean and alleviates adverse effects of salinity stress. International Journal of Plant Biology 1:e1.

Munns, R., and Tester, M. 2008. Mechanisms of salinity tolerance. Annual Review of Plant Biology 59:651-681.

Peng, S.B., Laza, R.C., Visperas, R.M., Khush, G.S., and Virk, P. 2004. Progress in breeding the new plant type for yield improvement: a physiological view. p. 130-132. In Toriyama, K., Heong, K.L., Hardy, B. (eds.) Rice is life: Scientific perspectives for the $21^{\text {st }}$ century. Proceedings of the World Rice Research Conference, Tsukuba, Japan. 4-7 November. International Rice Research Institute, Los Baños, Philippines, and Japan International Research Center for Agricultural Sciences, Tsukuba, Japan.

Pitann, B., Kranz, T., Zörb, C., Walter, A., Schurr, U., and Mühling, K.H. 2011. Apoplastic pH and growth in expanding leaves of Vicia faba under salinity. Environmental and Experimental Botany 74:31-36.

Prasad, S.R., Bagali, P.G., Hittalmani, S., and Shashidhar, H. 2000. Molecular mapping of quantitative trait loci associated with seedling tolerance to salt stress in rice (Oryza sativa L.) Current Science 78(2):162-164.

Song, X., Zhou, G., Ma, B.-L., Wu, W., Ahmad, I., Zhu, G., et al. 2019. Nitrogen application improved photosynthetic productivity, chlorophyll fluorescence, yield and yield components of two oat genotypes under saline conditions. Agronomy 9(3): 115.

Touchette, B.W., and Burkholder, J.M. 2007. Carbon and nitrogen metabolism in the seagrass, Zostera marina L.: environmental control of enzymes involved in carbon allocation and nitrogen assimilation. Journal of Experimental Marine Biology and Ecology 350:216-233.

Usman, K., Khan, E.A., Khan, N., Khan, M.A., Ghulam, S., Khan, S., et al. 2013. Effect of tillage and nitrogen on wheat production, economics, and soil fertility in rice-wheat cropping system. American Journal of Plant Sciences 4(1):17-25.

Wang, J., Guo, C., Dai, Q., Feng, B., Zuo, K., and Lin, M. 2016. Salt tolerance conferred by expression of a global regulator IrrE from Deinococcus radiodurans in oilseed rape. Molecular Breeding 36:88.

Wang, J., Lu, Y.-p., Wang, J., Xu, R.-X., Li, J., Hu, W., et al. 2018. Effects of elevated nitrogen application on nitrogen partitioning, plant growth, grain quality and key genes involved in glutamate biosynthesis among three rice genotypes. Chilean Journal of Agricultural Research 78:152-164.

Willekens, H., Chamnongpol, S., Davey, M., Schraudner, M., Langebartels, C., Van Montagu, M., et al. 1997. Catalase is a sink for $\mathrm{H}_{2} \mathrm{O}_{2}$ and is indispensable for stress defence in $\mathrm{C}_{3}$ plants. The EMBO Journal 16:4806-4816.

Zhu, G., Peng, S., Huang, J., Cui, K., Nie, L., and Wang, F. 2016. Genetic improvements in rice yield and concomitant increases in radiation-and nitrogen-use efficiency in middle reaches of Yangtze river. Scientific Reports 6:21049. 